\title{
A continuous-flow and on-site mesocosm for ocean acidification experiments on benthic organisms
}

\author{
Ju-Hyoung Kim¹, Eun Ju Kang ${ }^{2}$, Keunyong Kim ${ }^{2,3}$ and Kwang Young Kim ${ }^{4, *}$ \\ ${ }^{1}$ Faculty of Marine Applied Biosciences, Kunsan National University, Gunsan 54150, Korea \\ ${ }^{2}$ Research Institute for Basic Science, Chonnam National University, Gwangju 61186, Korea \\ ${ }^{3}$ Korea Ocean Satellite Center, Korea Institute of Ocean Science and Technology, Busan 49111, Korea \\ ${ }^{4}$ Department of Oceanography, College of Natural Sciences, Chonnam National University, Gwangju 61186, Korea
}

\begin{abstract}
Mesocosm experiments conducted for ecological purposes have become increasingly popular because they can provide a holistic understanding of the biological complexities associated with natural systems. This paper describes a new outdoor mesocosm designed for $\mathrm{CO}_{2}$ perturbation experiments of benthos. Manipulated the carbonate chemistry in a continuous flow-through system can be parallelized with diurnal changes, while irradiance, temperature, and nutrients can vary according to the local environment. A target hydrogen ion activity $(\mathrm{pH})$ of seawater was sufficiently stabilized and maintained within $4 \mathrm{~h}$ after dilution, which was initiated by the ratio of $\mathrm{CO}_{2}$-saturated seawater to ambient seawater. Specifically, $\mathrm{pH}$ and $\mathrm{CO}_{2}$ partial pressure $\left(\mathrm{pCO}_{2}\right)$ levels gradually varied from 8.05-7.28 and 375-2,691 $\mu$ atm, respectively, over a range of dilution ratios. This mesocosm can successfully manipulate the $\mathrm{pH}$ and $\mathrm{pCO}_{2}$ of seawater, and it demonstrates suitability for ocean acidification experiments on benthic communities.
\end{abstract}

Key Words: carbonate chemistry; $\mathrm{CO}_{2}$ partial pressure; continuous flow-through system; ocean acidification

\section{INTRODUCTION}

Changes in the relative fraction of inorganic carbonate species in the ocean driven by ocean acidification (OA) account for many ecological consequences that result from the biochemical and physiological responses of marine organisms to climatic change (Doney et al. 2009, Sunday et al. 2017). There have been many attempts to extrapolate the ecological effects of acidified seawater in small and tightly controlled laboratory experiments to great biological diversity and structural complexity of natural ecosystems. The superlative environmental conditions of natural carbon dioxide $\left(\mathrm{CO}_{2}\right)$ and hydrogen ion activity $(\mathrm{pH})$ gradients (e.g., volcanic $\mathrm{CO}_{2}$ vents) are truly appropriate to study the effects of naturally acidified seawater on marine communities (Hall-Spencer et al. 2008, Kroeker et al. 2011). Volcanic vents influence carbonate chemistry, creating a gradient of decreasing $\mathrm{pH}$ along a shallow rocky bottom and allow the integration of species interactions and seasonal cycles, unlikely to be achieved under laboratory settings (Ravaglioli et al. 2017). With few exceptions, on-site mesocosm studies have been performed persistently to assess the response of marine organisms to changes in carbonate chemistry (Petersen et al. 2009, Barry et al. 2010, Stewart et al. 2013).

The experimental manipulation of an ecosystem in a
(9) $\$$ This is an Open Access article distributed under the terms of the Creative Commons Attribution Non-Commercial License (http://creativecommons.org/licenses/by-nc/3.0/) which permits unrestricted non-commercial use, distribution, and reproduction in any medium, provided the original work is properly cited.
Received August 5, 2018, Accepted November 10, 2018

*Corresponding Author

E-mail: kykim@chonnam.ac.kr

Tel: +82-62-530-3465, Fax: +82-62-530-0065 
mesocosm can be used to generate a variety of realistic responses to OA conditions; however, it is difficult to manipulate the experimental conditions to the extent demanded by the dynamic ranges in natural environments (Duarte et al. 2015). Small-scale experiments to predict ecosystem responses, including laboratory mesocosms, are easy to control, but are not realistic (Petersen et al. 2009, Jeong et al. 2016). Meanwhile, laboratories or field mesocosm facilities have been recognized as powerful platforms for evaluating the ecological responses of marine organisms to a wide variety of natural and anthropogenic environments because they contain various ecosystem constituents, including biological and chemical processes (Riebesell et al. 2008).

There are several in situ mesocosm studies on the effect of simulated future conditions on the pelagic primary production and food web associated with biogeochemical cycles (Kim et al. 2008, Riebesell et al. 2013). Conversely, predicting the impact of carbonate chemistry changes in a high $\mathrm{CO}_{2}$ world on benthic communities is difficult because of the intricate interactions between biotic and abiotic components (Widdicombe et al. 2010). Numerous OA studies on benthic organisms rely mostly on laboratory experiments at small spatiotemporal scales (Widdicombe et al. 2010). Few studies have been conducted using an outdoor benthic mesocosm (Burrell et al. 2015, Wahl et al. 2015); however, the facilities are considered to be complicated to manipulate $\mathrm{CO}_{2}$ concentration and are expensive to install and maintain. In addition, several studies of benthos have used an enclosed tank system without seawater flow that utilized certified mixture of air- $\mathrm{CO}_{2}$ gases to create elevated $\mathrm{CO}_{2}$ conditions (Jokiel et al. 2008, Jiang et al. 2010, Kang and Kim 2016).

It is difficult to maintain consistent $\mathrm{CO}_{2}$ measurements in an open continuous flow-through system containing running seawater. This may not be able to afford the necessary insight regarding the patterns and processes of benthos in relation to experimental manipulations due to several limitations such as nutrient and trace element depletion, decomposition of organic matter, and so on. We expect that an on-site benthic mesocosm will provide many benefits for estimating benthic-pelagic coupling for biogeochemical exchanges and biological interactions. In doing so, it will allow for the easy manipulation of desired $\mathrm{CO}_{2}$ concentrations by using the seawater dilution ratio between ambient and $\mathrm{CO}_{2}$-saturated seawaters, whenever it is required.

\section{MATERIALS AND METHODS}

\section{Mesocosm facility and $\mathrm{pCO}_{2}$ perturbation system}

The mesocosm was installed near the rocky shore of Namhae-gun, South Sea of Korea $\left(34^{\circ} 48^{\prime} 30^{\prime \prime}\right.$ N, 127 $49^{\prime} 37^{\prime \prime}$ E), and consisted of cylindrical acrylic tanks (1.2 $\mathrm{m}$ in diameter and $1.2 \mathrm{~m}$ in height) that were transparent and lidless (Figs 1 \& 2). Coastal seawater was sequentially pumped at the rate of $100 \mathrm{~L} \mathrm{~min}^{-1}$ into the reservoir $(5 \mathrm{t}$ capacity) through a $300 \mu \mathrm{m}$ mesh screen to remove largesized organisms, detritus, and sediments. The pumps were designed to be self-priming (PA-1688, Agricultural \& Industrial Pumps, 2 Horsepower Capacity; Hanil Electric Co., Daejeon, Korea) and able to pump seawater used earlier for $\mathrm{CO}_{2}$ manipulation to the reservoir. The inflow rate of seawater from the reservoir to the mesocosm tanks remained constant during the experimental period. It was controlled by seawater inlet pipes with a pit diameter (approximately $9 \mathrm{~L} \mathrm{~min}^{-1}$ with $7 \mathrm{~mm}$ pit diameter). After the tank was filled with a $10 \mathrm{~cm}$ layer of sand and gravel taken from a nearby site, seawater was added through the water supply pipe until the outlet pipe overflowed (Fig. 2). The volume of seawater in each tank was approximately $1,250 \mathrm{~L}$. Nine tanks were arranged in a row in a north-south direction to achieve same lighting conditions during the daytime. To attain and maintain the target $\mathrm{pCO}_{2}$ or $\mathrm{pH}$ values in tank seawater, $\mathrm{CO}_{2}{ }^{-}$ saturated seawater was added to the seawater through the inflow pipe using a high-precision peristaltic pump (Masterflex Pump 7523-57; Cole-Parmer Instrument Co., Niles, IL, USA). $\mathrm{CO}_{2}$-saturated seawater was generated by bubbling commercially prepared pure $\mathrm{CO}_{2}$ gas, which achieved the seawater $\mathrm{pH}$ to drop below 5 .

\section{Regulation of carbonate chemistry by dilution ratio}

Varied $\mathrm{pH}$ or $\mathrm{pCO}_{2}$ levels were manipulated by dilution ratios of $\mathrm{CO}_{2}$-saturated seawater to ambient seawater. The flow rates of $\mathrm{CO}_{2}$-saturated seawater flowing through the inlet pipe were precisely controlled by peristaltic pumps at nine steps with a range of $0-85 \mathrm{~mL} \mathrm{~min}^{-1}$, where ambient seawater flowed into the mesocosm tanks constantly at a rate of $8.5 \mathrm{~L} \mathrm{~min}^{-1}$. Seawater samples were collected and analyzed for carbonate chemistry from each tank every 30 min (9 times) over a 4 -h period, after dilution was initiated. This experiment was designed to determine the optimal time for constructing stable $\mathrm{pH}$ or $\mathrm{pCO}_{2}$ levels, and was conducted in September 2013 when 


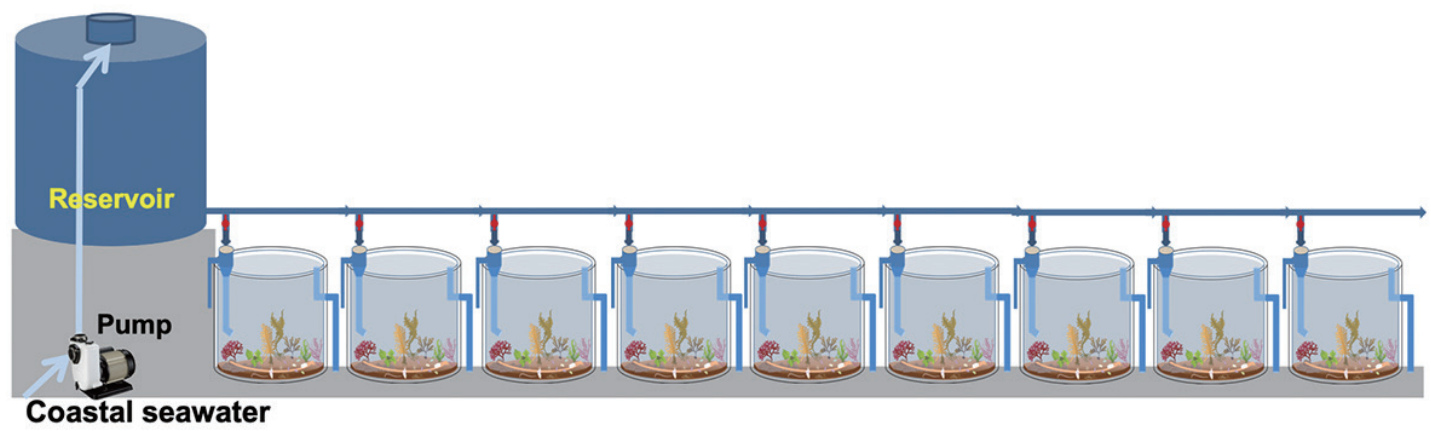

Fig. 1. Diagram of continuous flow-through mesocosm system for optimized benthic ocean acidification research. [Colour figure can be viewed at http://www.e-algae.org].

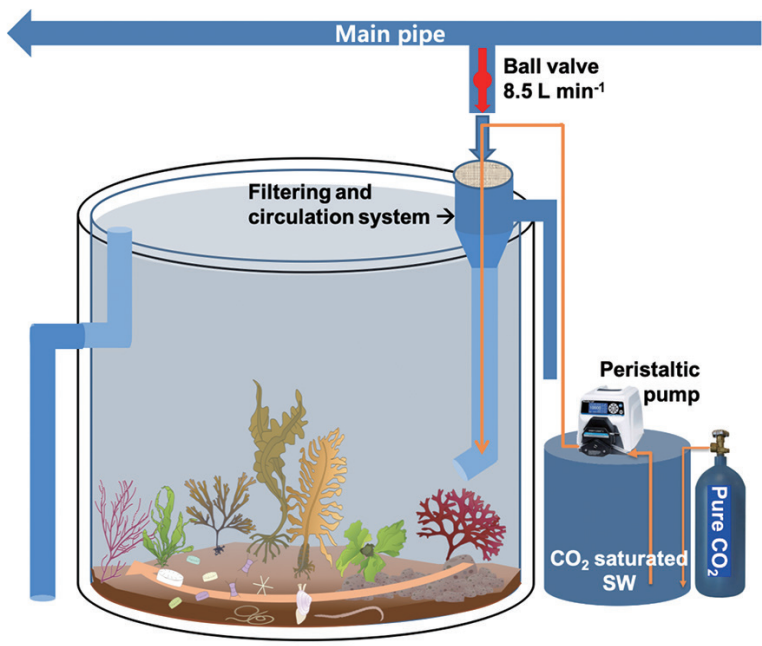

Fig. 2. Diagram of continuous flow-through mesocosm tank with a seawater filtering and circulation system. Inlet ambient seawater flow speed was fixed by gravity and pressure from main water tank ( $5 \mathrm{t}$ ). [Colour figure can be viewed at http://www.e-algae.org].

seawater temperatures ranged from 26 to $27^{\circ} \mathrm{C}$ with a salinity of $31 \mathrm{psu}$.

\section{Daily fluctuation of carbonate chemistry by dilu- tion ratio}

Ambient and two elevated $\mathrm{pCO}_{2}$ levels were created to monitor daily fluctuations of carbonate chemistry in coastal seawater. These conditions were constructed by two inflow rates of $\mathrm{CO}_{2}$-saturated seawater, specifically $25 \mathrm{~mL} \mathrm{~min}^{-1}$ (dilution ratio $=0.003$ and $0.2 \mathrm{pH}$ unit dropped) and $50 \mathrm{~mL} \mathrm{~min}^{-1}$ (dilution ratio $=0.006$ and 0.5 $\mathrm{pH}$ unit dropped). The flow rate of ambient seawater was fixed at approximately $9 \mathrm{~L} \mathrm{~min}^{-1}$. Using the siphon tubing, seawater samples were carefully collected from the mesocosm tanks at a depth of $0.5 \mathrm{~m}$ every $3 \mathrm{~h}$ over a $24-\mathrm{h}$ period. This experiment was performed with triplicate mesocosm tanks for each $\mathrm{CO}_{2}$ condition $(\mathrm{n}=3)$ and was conducted on Oct 24-25, 2013, when seawater temperatures ranged from 18 to $21^{\circ} \mathrm{C}$ with a salinity of $29 \mathrm{psu}$.

\section{Determination of carbonate chemistry}

Carbonate chemistry was analyzed based on the standard operation procedure for ocean $\mathrm{CO}_{2}$ measurements (Dickson et al. 2007). Seawater samples were collected by siphoning from the mid-depths of the tank and filled 500 $\mathrm{mL}$ borosilicate airtight glass bottles (1,500-500 Pyrex; Corning, NY, USA). The bottles were immediately closed with high quality vacuum grease (Apiezon M grease; M\&I Materials Ltd., Manchester, UK) after poisoning them with mercuric chloride $\left(\mathrm{HgCl}_{2}\right)$, and keeping them in a cold room prior to analysis.

The total alkalinity $\left(A_{\mathrm{T}}\right)$ and $\mathrm{pH}$ of seawater samples were analyzed within two days after acquisition and were used to calculate seawater carbonate chemistry with CO2SYS software (Lewis and Wallace 1998). The $A_{\mathrm{T}}$ was measured in the laboratory by a potentiometric acid titration system at a constant temperature of $25^{\circ} \mathrm{C}$. This system consists of a Metrohm 765 Dosimat titrator (Metrohm, Zofingen, Switzerland) and Orion 920A pH meter connected with a ROSS half-cell pH electrode (8101BNWP) and a reference electrode (Orion 900200) (Thermo Fisher Scientific, Waltham, MA, USA). Potentiometry measurements of electromotive force of the $\mathrm{pH}$ electrode and the volume of added hydrochloric acid $(\mathrm{HCl})$ were acquired semi-automatically using a Q-basic program (Millero et al. 1993).

Seawater $\mathrm{pH}$ was determined with spectrophotometric measurements using a high-resolution spectrophotometer (Agilent 8453 UV-Visible Spectrophotometer; Agilent Technologies, Pal Alto, CA, USA). Using a siphon tube, the samples were filled into a $10 \mathrm{~cm}$ path length cuvette without air bubbles, and then, absorbance was measured 

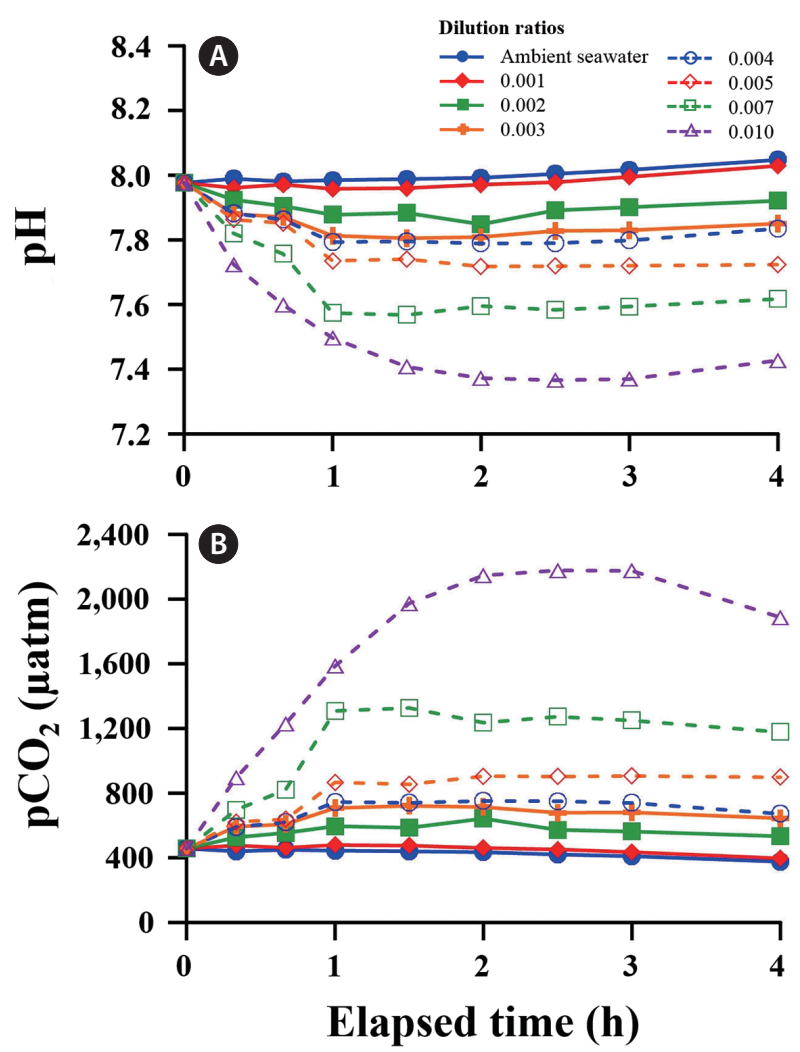

Fig. 3. The $\mathrm{pH}(\mathrm{A})$ and $\mathrm{pCO}_{2}$ concentrations $(\mathrm{B})$ in the seawater with various dilution ratios of $\mathrm{CO}_{2}$-saturated to ambient seawaters over $4 \mathrm{~h}$. [Colour figure can be viewed at http://www.e-algae.org].

with or without adding an indicator dye at wavelengths of 434,578 , and $730 \mathrm{~nm}$ and a constant temperature of $25^{\circ} \mathrm{C}$. The perturbation of the indicator metacresol purple (Sigma-Aldrich Chemical Co., St. Louis, MO, USA) on the $\mathrm{pH}$ was used (Dickson 1993). The precision of $\mathrm{pH}$ and $A_{\mathrm{T}}$ was checked using certified reference materials (certified by Dickson, A., Scripps Institution of Oceanography, San Diego, CA, USA) and was approximately \pm 0.004 unit for $\mathrm{pH}$ and $\pm 2 \mu \mathrm{mol} \mathrm{kg}{ }^{-1}$ for $A_{\mathrm{T}}$.

\section{RESULTS}

\section{Regulation of carbonate chemistry by dilution ratio}

A wide range of $\mathrm{pH}$ and $\mathrm{pCO}_{2}$ can be controlled by adjusting the dilution ratios between ambient and $\mathrm{CO}_{2}-$ saturated seawaters. After adding $\mathrm{CO}_{2}$-saturated seawater to the tanks, initial $\mathrm{pH}$ (7.98) and $\mathrm{pCO}_{2}(452 \mu \mathrm{atm})$ of ambient seawater changed rapidly and reached a steady
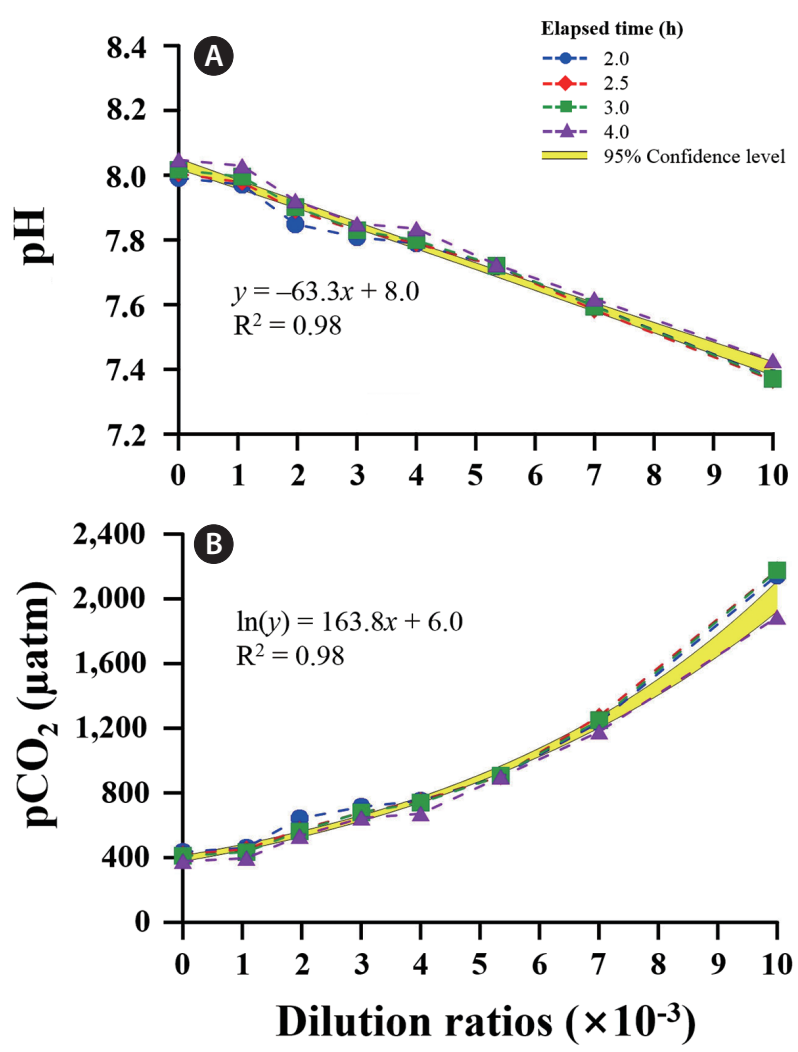

Fig. 4. The $\mathrm{pH}(\mathrm{A})$ and $\mathrm{pCO}_{2}$ concentrations $(\mathrm{B})$ as a function of dilution ratio with the addition of $\mathrm{CO}_{2}$-saturated seawater into an inlet pipe of ambient seawater. Different symbols and lines represent the time elapsed $2 \mathrm{~h}$ after dilution was initiated. The shading denotes the $95 \%$ confidence intervals. [Colour figure can be viewed at http:// www.e-algae.org].

state level of pH 7.30 and $\mathrm{pCO}_{2}$ ca. 2,600 $\mu$ atm within $4 \mathrm{~h}$ (Fig. 3). In all tanks, $\mathrm{CO}_{2}$-induced changes in carbonate chemistry achieved a plateau level of $80 \%$ after $1 \mathrm{~h}$. A significant negative correlation was observed between $\mathrm{pH}$ and the dilution ratio of $\mathrm{CO}_{2}$-saturated to ambient seawaters $\left(\mathrm{R}^{2}=0.98\right)$. The $\mathrm{pCO}_{2}$ increased exponentially with increasing dilution ratio (Fig. 4).

\section{Daily fluctuation of carbonate chemistry by dilu- tion ratio}

In general, the trend in carbonate chemistry in both ambient and acidified seawaters is close to a cosine curve over the time of day, regardless of the light and dark cycle (Fig. 5). The $\mathrm{pH}$ and carbonate ion $\left(\mathrm{CO}_{3}{ }^{2-}\right)$ values gradually increased with increasing irradiance during the daytime (from 9:00 am to 3:00 pm), whereas dissolved inorganic carbon (DIC), $\mathrm{pCO}_{2}$, and bicarbonate $\left(\mathrm{HCO}_{3}{ }^{-}\right)$ values decreased. The highest $\mathrm{pH}$ of $7.96 \pm 0.01$ was re- 

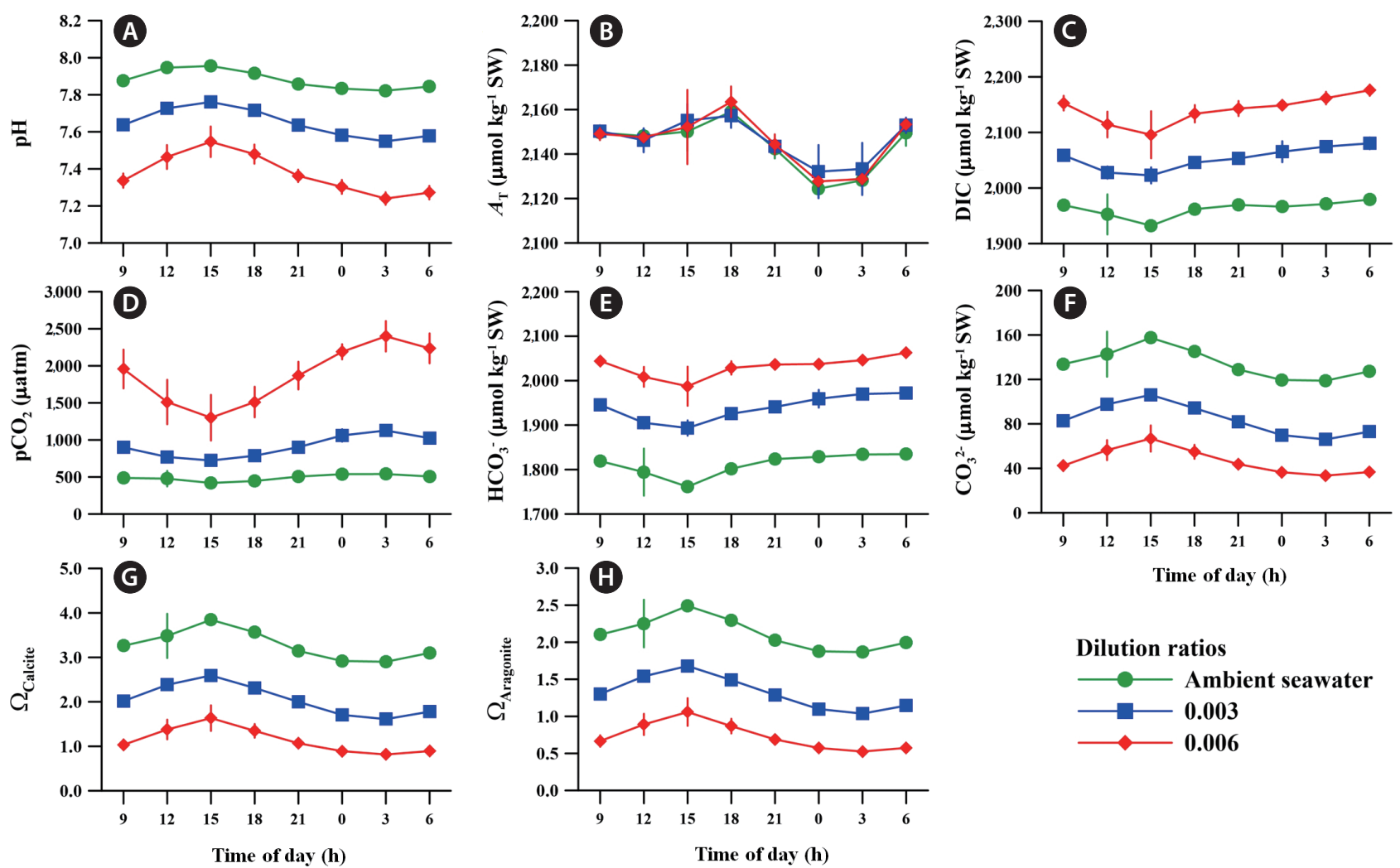

\section{Dilution ratios}

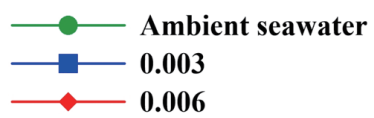

Fig. 5. Daily fluctuations in carbonate chemistry: seawater $\mathrm{pH}(\mathrm{A})$, total alkalinity $\left(A_{\mathrm{T}}\right)(\mathrm{B})$, total dissolved inorganic carbon (DIC) (C), seawater partial pressure of $\mathrm{CO}_{2}\left(\mathrm{pCO}_{2}\right)(\mathrm{D})$, bicarbonate ion $\left(\mathrm{HCO}_{3}{ }^{-}\right)(\mathrm{E})$, carbonate ion $\left(\mathrm{CO}_{3}{ }^{2-}\right)(\mathrm{F})$, saturation state of calcite $\left(\Omega_{\text {calcite }}\right)(\mathrm{G})$, and saturation state of aragonite $\left(\Omega_{\text {Aragonite }}\right)(H)$ under ambient and two different ocean acidification conditions. Error bars represent the standard deviation from the mean of replicate enclosures $(n=3)$. [Colour figure can be viewed at http://www.e-algae.org].

corded on the same day that the irradiance reached its peak power at 3:00 pm, while its value was $7.88 \pm 0.01$ at the beginning $(9: 00 \mathrm{am})$ (Fig. 5A). The $\mathrm{pCO}_{2}$ value of ambient seawater decreased from $487 \pm 8$ to $419 \pm 2 \mu \mathrm{atm}$ during this period (Fig. 5D).

The decline in $\mathrm{pH}$ and increase in $\mathrm{pCO}_{2}$ occurred from 3:00 pm to 3:00 am, which correlates with the fact that respiration exceeds photosynthesis as irradiance decreased. During these hours, it reached the lowest $\mathrm{pH}$ and the highest $\mathrm{pCO}_{2}$ values at 3:00 am in ambient conditions. Specifically, the fluctuations of DIC, $\mathrm{HCO}_{3}{ }^{-}$, and $\mathrm{CO}_{3}{ }^{2-}$ in ambient seawater demonstrated a countertrend between the hours of day and night.

The $\mathrm{pCO}_{2}$ values in the OA conditions with dilution ratios of 0.003 and 0.006 were $84 \%(899 \pm 29 \mu \mathrm{atm})$ and $300 \%(1,957 \pm 261 \mu \mathrm{atm})$ higher than that in ambient conditions. The $\mathrm{pH}$ and $\mathrm{pCO}_{2}$ levels in acidified seawater followed the same patterns in ambient seawater and exhibited a larger amplitude in daily fluctuations than in ambient conditions. Other carbonate chemical parame- ters including $\mathrm{HCO}_{3}, \mathrm{CO}_{3}{ }^{2-}$, DIC, calcium carbonate state $\left(\Omega_{\text {Calcite }}\right)$, and aragonite saturation state $\left(\Omega_{\text {Aragonite }}\right)$ in OA conditions also fluctuated in parallel with those of ambient conditions. The $A_{\mathrm{T}}$ varied slightly from $2,214 \pm 2$ to $2,159 \pm 0 \mu \mathrm{mol} \mathrm{kg}^{-1} \mathrm{SW}$ during the day despite significant level changes in other carbonate parameters over time (Fig. 5B).

\section{DISCUSSION}

Research on OA has increased rapidly in recent years with growing concerns about climate change. We designed a cost efficient mesocosm facility for an OA experiment that applies an outdoor continuous flow-through tank system. Generally, a benthic mesocosm requires a higher degree of specificity for its experimental setup to appropriately reflect different target populations or communities. There are various mesocosm approaches suggested for the ecological evaluation of OA on marine 
benthic organisms; however, many facilities are required to resolve the associated problems including high costs and degree of reality achieved. In previous studies, the elevated $\mathrm{CO}_{2}$ conditions were often aerated with the premixed $\mathrm{CO}_{2}$ gas (Alexandre et al. 2012, Pansch et al. 2016), and they required a large amount of mixed gases to manipulate OA conditions, in addition to being expensive (more than US \$200 per $50 \mathrm{~L}$ gas cylinder).

Andersson et al. (2009) designed a continuous flowthrough system that was adjusted with weak $\mathrm{HCl}$ to maintain elevated $\mathrm{CO}_{2}$ conditions. However, this method causes a fractional shift in the seawater's carbonate chemistry, which is dissimilar to natural OA conditions. For example, a greater fractionation of DIC $\left(\mathrm{HCO}_{3}{ }^{-}\right.$and $\mathrm{CO}_{3}{ }^{2-}$ ) shifts towards more $\mathrm{CO}_{2}$, and this process can change the total alkalinity of seawater while DIC remains unchanged. Alternatively, the compressed $\mathrm{CO}_{2}$ gas flowed into the submerged water pump with a gas control valve to create high $\mathrm{CO}_{2}$ conditions, and this system was applied to a natural seagrass habitat (Campbell and Fourqurean 2011). Another low-cost tank system was implemented to regulate $\mathrm{CO}_{2}$ inflow with a peristaltic pump that controlled $\mathrm{CO}_{2}$ flow and a microfine bubble diffuser (Jokiel et al. 2014).

In this study, we have suggested a novel mesocosm that was adopted on-site using low-cost and easy-to-use platforms to control $\mathrm{CO}_{2}$ concentration. Seawater carbonate chemistry was adjusted by adding calculated quantities of $\mathrm{CO}_{2}$-saturated seawater to ambient seawater, for which the DIC was known and had a similar shift in all tanks that corresponded with the desired treatments. The addition of $\mathrm{CO}_{2}$-saturated seawater is a more effective method for creating acidified seawater, as compared to methods involving $\mathrm{CO}_{2}$ bubbling and adding weak $\mathrm{HCl}$ (Kim et al. 2010, 2016, Riebesell et al. 2010). This technique has not been previously applied to OA research for marine benthos. It is considered one of the most efficient methods that allows for the carbonate chemistry to quickly reach the target value from the ambient value. This pumping system can achieve the desired $\mathrm{CO}_{2}$ levels quickly with a short seawater residence time of approximately $2.5 \mathrm{~h}$ in the tank, and it can realize the target level of $80 \%$ in $1 \mathrm{~h}$. Another important point is that the dilution ratio of $\mathrm{CO}_{2}$-saturated seawater to ambient seawater can be readily applied for running $\mathrm{OA}$ experiments in the field. The addition of $\mathrm{CO}_{2}$-saturated seawater was regulated with a high-precision peristaltic pump that controlled the flow rate in a range of $0-85 \mathrm{~mL} \mathrm{~min}^{-1}$ and kept the flow rate constant for a given period of time. An additional advantage is that the use of a continuous flow- through systems allows for pulsed exposure to be more realistically simulated with diel fluctuations in seawater carbonate chemistry, as well as other environmental factors, during the experiment.

Marine benthic autotrophs (e.g., macroalgae and seagrass) experience dynamic changes in $\mathrm{CO}_{2}$ and $\mathrm{pH}$ in respect to photosynthesis and respiration (Jiang et al. 2011, Kim et al. 2015). The magnitude of $\mathrm{pCO}_{2}$ fluctuations is greater in coastal areas (e.g., upwelling, estuary, near shore, coral reef, and kelp forests) than in the open ocean, and are mainly determined by biological processes (Hofmann et al. 2011). Variations of $\mathrm{pCO}_{2}$ in seagrass beds ranged from 240 to $1,488 \mu \mathrm{atm}$, representing changes in biological activity with daily or seasonal fluctuations (Saderne et al. 2013). Additionally, $\mathrm{pCO}_{2}$ survey in a giant kelp forest identified a strong relationship with that of surrounded seawater (Frieder et al. 2012). Because our mesocosm is designed to produce rapid mixing and is subject to natural fluctuations in $\mathrm{pCO}_{2}$, it is useful to explore the biological consequences of $\mathrm{OA}$ in more realistic field conditions.

As $\mathrm{pH}$ decreased, the $\mathrm{pCO}_{2}$ increased exponentially, which is expected under climate change scenarios (Fig. 4). Diel fluctuations of $\mathrm{pCO}_{2}$ was large at elevated $\mathrm{CO}_{2}$ conditions; however, $\mathrm{pH}$ was lower and changed in parallel with ambient conditions (Fig. 5). Generally, seawater $\mathrm{pCO}_{2}$ increased exponentially at the $\mathrm{pH}$ range from the pre-industrial revolution (approximately 8.2) to future climate scenarios, which is predicted to decrease $\mathrm{pH}$ by 0.5 units by 2,100 (Raven et al. 2005). The changes in carbonate chemistry speciation in mesocosm tanks are largely induced by intensive biogeochemical process such as photosynthesis, respiration, and decomposition of marine biota in various ways. From these aspects, our field mesocosm is suitable for fulfilling ecological requirements and can be used for gauging responses of coastal ecosystems where the dynamics of carbonate chemistry are mainly affected by biological processes.

All facilities can be supplied at a reasonable price (e.g., small water tank, pure $\mathrm{CO}_{2}$ gas, and peristaltic pump), which is a major advantage over the other techniques previously used for outdoor mesocosm studies. Moreover, this technique has a fast response time and it is feasible for manipulating carbonate chemistry of seawater to reach desired levels of $\mathrm{pCO}_{2}$ and total alkalinity. However, high quality carbonate chemistry measurements are required in order to fully understand the dynamics of a carbonate system in ambient and acidified treatments. In order to satisfy this requirement, the precision of seawater $\mathrm{pH}$ measurements must be better than $0.002 \mathrm{pH}$ 
units (Rérolle et al. 2012). In this study, the dilution method using $\mathrm{CO}_{2}$-saturated seawater highlighted the cost efficiency and technical feasibility for creating desired $\mathrm{CO}_{2}$ conditions, as well as the advantage of representing the fluctuations in carbonate chemistry for various coastal environments.

\section{ACKNOWLEDGEMENTS}

The authors thank K. T. Park (fishing village chief in Jakjang-ri) for providing the field site to install a mesocosm facility and D. H. Kang (Ewha Aquaculture) for technical support. This work was supported by the Management of Marine Organisms Causing Ecological Disturbance and Harmful Effects program (KIMST/MOF), NRF-2016R1A6A1A03012647 and Chonnam National University in 2016.

\section{REFERENCES}

Alexandre, A., Silva, J., Buapet, P., Björk, M. \& Santos, R. 2012. Effects of $\mathrm{CO}_{2}$ enrichment on photosynthesis, growth, and nitrogen metabolism of the seagrass Zostera noltii. Ecol. Evol. 2:2625-2635.

Andersson, A. J., Kuffner, I. B., Mackenzie, F. T., Jokiel, P. L., Rodgers, K. S. \& Tan, A. 2009. Net loss of $\mathrm{CaCO}_{3}$ from a subtropical calcifying community due to seawater acidification: mesocosm-scale experimental evidence. Biogeosciences 6:1811-1823.

Barry, J. P., Hall-Spencer, J. M. \& Tyrrell, T. 2010. In situ perturbation experiments: natural venting sites, spatial/ temporal gradients in ocean $\mathrm{pH}$, manipulative in situ $\mathrm{p}\left(\mathrm{CO}_{2}\right)$ perturbations. In Riebesell, U., Fabry, V. J. \& Gattuso, J. -P. (Eds.) Guide for Best Practices in Ocean Acidification Research and Data Reporting. Publications Office of the European Union, Luxembourg, pp. 123-136.

Burrell, R. B., Keppel, A. G., Clark, V. M. \& Breitburg, D. L. 2015. An automated monitoring and control system for flow-through co-cycling hypoxia and $\mathrm{pH}$ experiments. Limnol. Oceanogr. Methods 14:168-185.

Campbell, J. E. \& Fourqurean, J. W. 2011. Novel methodology for in situ carbon dioxide enrichment of benthic ecosystems. Limnol. Oceanogr. Methods 9:97-109.

Dickson, A. G. 1993. The measurement of sea water pH. Mar. Chem. 44:131-142.

Dickson, A. G., Sabine, C. L. \& Christian, J. R. 2007. Guide to best practices for ocean $\mathrm{CO}_{2}$ measurements. PICES Special Publication 3. North Pacific Marine Science Organi- zation, Sydney, $191 \mathrm{pp}$.

Doney, S. C., Fabry, V. J., Feely, R. A. \& Kleypas, J. A. 2009. Ocean acidification: the other $\mathrm{CO}_{2}$ problem. Annu. Rev. Mar. Sci. 1:169-192.

Duarte, G., Calderon, E. N., Pereira, C. M., Marangoni, L. F. B., Santos, H. F., Peixoto, R. S., Bianchini, A. \& Castro, C. B. 2015. A novel marine mesocosm facility to study global warming, water quality and ocean acidification. Ecol. Evol. 5:4555-4566.

Frieder, C. A., Nam, S. H., Martz, T. R. \& Levin, L. A. 2012. High temporal and spatial variability of dissolved oxygen and $\mathrm{pH}$ in a nearshore California kelp forest. Biogeosciences 9:3917-3930.

Hall-Spencer, J. M., Rodolfo-Metalpa, R., Martin, S., Ransome, E., Fine, M., Turner, S. M., Rowley, S. J., Tedesco, D. \& Buia, M. -C. 2008. Volcanic carbon dioxide vents show ecosystem effects of ocean acidification. Nature 454:96-99.

Hofmann, G. E., Smith, J. E., Johnson, K. S., Send, U., Levin, L. A., Micheli, F., Paytan, A., Price, N. N., Peterson, B., Takeshita, Y., Matson, P. G., Crook, E. D., Kroeker, K. J., Gambi, M. C., Rivest, E. B., Frieder, C. A., Yu, P. C. \& Martz, T. R. 2011. High-frequency dynamics of ocean pH: a multi ecosystem comparison. PLoS ONE 6:e28983.

Jeong, H. J., Lee, K., Yoo, Y. D., Kim, J. -M., Kim, T. H., Kim, M., Kim, J. -H. \& Kim, K. Y. 2016. Reduction in $\mathrm{CO}_{2}$ uptake rates of red tide dinoflagellates due to mixotrophy. Algae 31:351-362.

Jiang, Z. J., Huang, X. -P. \& Zhang, J. -P. 2010. Effects of $\mathrm{CO}_{2}$ enrichment of photosynthesis, growth, and biochemical composition of seagrass Thalassia hemprichii (Ehrenb.) Aschers. J. Integr. Plant Biol. 52:904-913.

Jiang, Z. -P., Huang, J. -C., Dai, M., Kao, S. J., Hydes, D. J., Chou, W. -C. \& Jan, S. 2011. Short-term dynamics of oxygen and carbon in productive nearshore shallow seawater systems off Taiwan: observation and modeling. Limnol. Oceanogr. 56:1832-1849.

Jokiel, P. L., Bahr, K. D. \& Rodgers, K. S. 2014. Low-cost, highflow mesocosm system for simulating ocean acidification with $\mathrm{CO}_{2}$ gas. Limnol. Oceanogr. Methods 12:313322.

Jokiel, P. L., Rodgers, K. S., Kuffner, I. B., Andersson, A. J., Cox, E. F. \& Mackenzie, F. T. 2008. Ocean acidification and calcifying reef organisms: a mesocosm investigation. Coral Reefs 27:473-483.

Kang, E. J. \& Kim, K. Y. 2016. Effects of future climate conditions on photosynthesis and biochemical component of Ulva pertusa (Chlorophyta). Algae 31:49-59.

Kim, J. -H., Kang, E. J., Edwards, M. S., Lee, K., Jeong, H. J. \& Kim, K. Y. 2016. Species-specific responses of temperate 
macroalgae with different photosynthetic strategies to ocean acidification: a mesocosm study. Algae 31:243256.

Kim, J. -H., Kang, E. J., Kim, K., Jeong, H. J., Lee, K., Edwards, M. S., Park, M. G., Lee, B. -G. \& Kim, K. Y. 2015. Evaluation of carbon flux in vegetative bay based on ecosystem production and $\mathrm{CO}_{2}$ exchange driven by coastal autotrophs. Algae 30:121-137.

Kim, J. -M., Lee, K., Yang, E. J., Shin, K., Noh, J. H., Park, K. -T., Hyun, B., Jeong, H. -J., Kim, J. -H., Kim, K. Y., Kim, M., Kim, H. -C., Jang, P. -G. \& Jang, M. -C. 2010. Enhanced production of oceanic dimethylsulfide resulting from $\mathrm{CO}_{2}$-induced grazing activity in a high $\mathrm{CO}_{2}$ world. Environ. Sci. Technol. 44:8140-8143.

Kim, J. -M., Shin, K., Lee, K. \& Park, B. -K. 2008. In situ ecosystem-based carbon dioxide perturbation experiments: design and performance evaluation of a mesocosm facility. Limnol. Oceanogr. Methods 6:208-217.

Kroeker, K. J., Micheli, F., Gambi, M. C. \& Martz, T. R. 2011. Divergent ecosystem responses within a benthic marine community to ocean acidification. Proc. Natl. Acad. Sci. USA. 108:14515-14520.

Lewis, E. \& Wallace, D. 1998. Program developed for $\mathrm{CO}_{2}$ system calculation. ORNL/CDICA-105. Carbon Dioxide Information Analysis Center, Oak Ridge National Laboratory, U.S. Department of Energy, Oak Ridge, TN, 21 pp.

Millero, F. J., Zhang, J. -Z., Lee, K. \& Campbell, D. M. 1993. Titration alkalinity of seawater. Mar. Chem. 44:153-165.

Pansch, A., Winde, V., Asmus, R. \& Asmus, H. 2016. Tidal benthic mesocosms simulating future climate change scenarios in the field of marine ecology. Limnol. Oceanogr. Methods 14:257-267.

Petersen, J. E., Kennedy, V. S., Dennison, W. C. \& Kemp, W. M. 2009. Enclosed experimental ecosystem and scale: tools for understanding and managing coastal ecosystems. Springer-Verlag, New York, 222 pp.

Ravaglioli, C., Lauritano, C., Buia, M. C., Balestri, E., Capocchi, A., Fontanini, D., Pardi, G., Tamburello, L., Procaccini, G. \& Bulleri, F. 2017. Nutrient loading fosters seagrass productivity under ocean acidification. Sci. Rep. 7:13732.

Raven, J., Caldeira, K., Elderfield, H., Hoegh-Guldberg, O., Liss, P., Riebesell, U., Shepherd, J., Turley, C. \&Watson, A. 2005. Ocean acidification due to increasing atmospheric carbon dioxide. Policy Document 12/05. The Royal Society, London, $60 \mathrm{pp}$.

Rérolle, V. M. C., Floquet, C. F. A., Mowlem, M. C., Connelly,
D. P., Achterberg, E. P. \& Bellerby, R. R. G. J. 2012. Seawater-pH measurements for ocean-acidification observations. Trends Anal. Chem. 40:146-157.

Riebesell, U., Bellerby, R. G. J., Grossart, H. -P. \& Thingstad, F. 2008. Mesocosm $\mathrm{CO}_{2}$ perturbation studies: from organism to community level. Biogeosciences 5:1157-1164.

Riebesell, U., Czerny, J., von Bröckel, K., Boxhammer, T., Büdenbender, J., Deckelnick, M., Fischer, M., Hoffmann, D., Krug, S. A., Lentz, U., Ludwig, A., Muche, R. \& Schulz, K. G. 2013. A mobile sea-going mesocosm system: new opportunities for ocean change research. Biogeosciences 10:1835-1847.

Riebesell, U., Lee, K. \& Nejstgaard. 2010. Pelagic mesocosms. In Riebesell, U., Fabry, V. J., Hansson, L. \& Gattuso, J. -P. (Eds.) Guide for Best Practices in Ocean Acidification Research and Data Reporting. Publications Office of the European Union, Luxembourg, pp. 95-112.

Saderne, V., Fietzek, P. \& Herman, P. M. J. 2013. Extreme variations of $\mathrm{pCO}_{2}$ and $\mathrm{pH}$ in a macrophyte meadow of the Baltic Sea in summer: evidence of the effect of photosynthesis and local upwelling. PLoS ONE 8:e62689.

Stewart, R. I. A., Dossena, M., Bohan, D. A., Jeppesen, E., Kordas, R. L., Ledger, M. E., Meerhoff, M., Moss, B., Mulder, C., Shurin, J. B., Suttle, B., Thompson, R., Trimmer, M. \& Woodward, G. 2013. Mesocosm experiments as a tool for ecological climate-change research. Adv. Ecol. Res. 48:71-181.

Sunday, J. M., Fabricius, K. E., Kroeker, K. J., Anderson, K. M., Brown, N. E., Barry, J. P., Connell, S. D., Dupont, S., Gaylord, B., Hall-Spencer, J. M., Klinger, T., Milazzo, M., Munday, P. L., Russell, B. D., Sanford, E., Thiyagarajan, V., Vaughan, M. L. H., Wilddicombe, S. \& Harley, C. D. G. 2017. Ocean acidification can mediate biodiversity shifts by changing biogenic habitat. Nat. Clim. Change 7:81-85.

Wahl, M., Buchholz, B., Winde, V., Golomb, D., Guy-Haim, T., Müller, J., Rilov, G., Scotti, M. \& Böttcher, M. E. 2015. A mesocosm concept for the simulation of near-natural shallow underwater climates: The Kiel Outdoor Benthocosms (KOB). Limnol. Oceanogr. Methods 13:651663.

Widdicombe, S., Dupont, S. \& Thorndyke, M. 2010. Laboratory experiments and benthic mesocosm studies. In Riebesell, U., Fabry, V. J., Hansson, L. \& Gattuso, J. -P. (Eds.) Guide for Best Practices in Ocean Acidification Research and Data Reporting. Publications Office of the European Union, Luxembourg, pp. 113-122. 